\title{
Money turmoil poses awkward questions
}

The world's foreign exchanges have been like bear-pits in the past few weeks, but the causes of the turmoil have long roots, in the US budget deficit and in most of Europe's tradition of tolerating inflation.

HeRE is an intellectual problem with practical as well as intellectual interest. Germany is in money trouble because of the Bonn government's failure to estimate the full social and money costs of reunification and because of the threat of inflation, signalled by the growth of the domestic money supply last month. Yet for the past three weeks, the Deutschemark has been riding high on the world's foreign exchanges - embarrassingly so. In the United States, on the other hand, inflation is lower than for decades and still falling, while the Federal Reserve has moved vigorously to stimulate economic growth by reducing interest rates to historically low levels. Yet the dollar has fallen precipitously in value against the Deutschemark (by roughly 20 per cent since the beginning of this year). A dollar will now buy much more in New York than will DM1.47 in Frankfurt; with even sterling stronger against the dollar (but weaker against the Deutschemark), the British Customs and Excise have thought it prudent to warn British travellers to the United States that they will have to pay tax on whatever bargains they find in North America. Why the difference?

The simple explanation is that German interest rates are now six or seven percentage points above those obtainable in the United States. Not only foreign exchange dealers, but companies and private persons seeking to make the best of their bank deposits, switch from accounts denominated in dollars to accounts denominated in Deutschemarks for the sake of the extra interest their money will earn. But that is only part of the story, and in particular does not explain why the flight from the dollar has now gone so far that it would probably be possible for German traders to satisfy the national demand for bratwurst and other such goods by buying in Chicago with cheap dollars and then paying the transport costs to Hamburg. (There would, of course, be European Community tariffs to pay, which is another tale.)

The more durable cause of the weakness of the dollar in the past few weeks is different, and is to be found in Washington. Estimating the annual US federal deficit is one of the few growth industries in the United States. Whether the final figure for this financial year (which ends this month) will be nearer to $\$ 400$ billion than $\$ 500$ billion remains conjecture. But it is now clear that countries such as Germany and Japan, which earn contentiously respectable trading surpluses, have other things to do with the proceeds of their surpluses than to return them to the United States to be used, directly or otherwise, to bridge the federal government's budget gap. The Federal Reserve's drive towards low interest rates can only have confirmed the resolve of foreigners not to help out the US administration. It is remarkable that none of this can be gleaned from the election campaign now under way.

The strength of the Deutschemark, relative to other European currencies as well as the US dollar, must be differently explained. Indeed, in the best sense of the phrase. it is a confidence trick. Over the years, the central bank (called the Bundesbank) has acquired such a fearsome reputation for monetary probity, confirmed by the increase of interest rates last month, that the investment community believes that eight per cent interest on Deutschemark deposits is a safer risk than, say, ten per cent in Britain or France or even seventeen per cent in Italian lire. In the past few weeks, the money changers have been betting on a realignment of European currencies - on a stronger Deutschemark and weaker currencies elsewhere, which would bring them capital profits as well as higher earnings.

How safe is that bet? If the street violence in Rostock over recent days had happened elsewhere, the local currency would no doubt have tumbled. But the exchange markets might also have been given pause by last week's decision by a US chipmaker to close its plant at Braunschweig on the grounds that German labour costs and practices make it unprofitable to operate expensive capital equipment there. (That, in the long run, will be the whole of Europe's problem.) More immediately, there is the chance that France may say NON at the referendum on the Maastricht Treaty less than three weeks from now; by illogically casting doubt on the viability of the whole European enterprise, that could make all European currencies less valuable against the dollar. But if the project for European monetary union has to be abandoned or postponed, it is difficult to see how revaluation of the Deutschemark could be avoided. That is what the European bets are about.

\section{FEMA's testing time}

The US federal agency with responsibility for national emergencies has flunked again.

IF emergency management, like charity, begins at home. then the victims of the hurricanes in Florida this season arc unlikely to get speedy succour from the Federal Emergenc! Management Agency (FEMA). That body has once again 